\title{
The Effects of Honey Administration on Petrol-Induced Oxidative Stress and Hepatotoxicity in Sprague-dawley Male Rats
}

Murtala Bello Abubakar ${ }^{1,2^{*}}$ and Boon Suen $\mathrm{ANG}^{3}$

${ }^{1}$ Department of Physiology, Faculty of Basic Medical Sciences, College of Health Sciences

${ }^{2}$ Centre for Advanced Medical Research and Training, Usmanu Danfodiyo University, P.M.B. 2254, Sokoto, Nigeria.

${ }^{3}$ Exercise and Sports Science Programme, School of Health Sciences, Universiti Sains Malaysia 16150 Kubang Kerian, Kelantan, Malaysia.

Corresponding author:

Murtala Bello Abubakar

${ }^{1}$ Department of Physiology, Faculty of Basic Medical

Sciences, College of Health Sciences,

Usmanu Dan Fodiyo University, PMB 2254 Sokoto,

Nigeria

E-Mail: murtala,bello@udusok.edu.ng;

Tel.: +234-80-35925103

\section{Abstract}

Background: Exposure to petrol is common among individuals working in oil refineries, oil fields, filling stations and automobile mechanical workshops. Exposure to petrol is associated with a number of health hazards including hepatotoxicity and oxidative stress. Honey is rich in many antioxidants such as catalase, flavonoids, thiamine, riboflavin, pyridoxine, pantothenic acid, ascorbic acid and nicotinic acid and was recently reported to reduce petrol-induced hepatotoxicity and nephrotoxicity.

Materials and Methods: A total of 32 male Sprague-Dawley rats were randomly divided into four groups: control group (exposed to ambient air daily), petrol exposed group (exposed to petrol vapours at $11.13 \pm 1.1 \mathrm{~cm}^{3} / \mathrm{h}, 6$ hours daily, six days per week + distilled water $0.5 \mathrm{ml}$ daily for $11 \mathrm{wks}$ ) honey treated group (treated with honey at $1.2 \mathrm{~g} / \mathrm{kg}$ body weight) and petrol + honey group (exposed to petrol vapours at $11.13 \pm 1.1 \mathrm{~cm}^{3} / \mathrm{h}, 6$ hours daily + honey at $1.2 \mathrm{~g} / \mathrm{kg}$ body weight daily for 11 weeks). The total body weight and liver weight of each rat were determined using a digital analytical balance.

Results: The results show that exposure to petrol was associated with significant weight loss and hepatomegaly $(p<0.001)$ and that honey administration did not result in any significant $(\mathrm{p}>0.05)$ improvement in these toxicities. No significant alterations were observed in the liver enzymes (AST, ALT and ALP) of petrol exposed group compared with the control group. The activity of glutathione peroxidase was found to be significantly elevated in rats that were exposed to petrol and treated with honey. The activity of glutathione reductase was also found to be significantly reduced $(p=0.035)$ in petrol exposed group.

Conclusion: Exposure to Malaysian petrol may be associated with less adverse effects and honey administration may not improve the petrol-induced hepatotoxicity associated with the petrol exposure.

Keywords: Petrol, oxidative stress, honey, hepatotoxicity, hepatomegaly 


\section{Introduction}

Petrol or gasoline is one of the products of crude oil that is commonly used as fuel for automobiles and other internal combustion engines. Many studies have observed that many of the ingredients found in petrol are highly toxic and carcinogenic to humans (1-3). There are many sources of exposure to petrol which include oil refineries, oil fields, filling stations, automobile mechanical workshops, losses from underground tanks, spillage and emissions from automobiles $(3,4)$. A number of studies has documented various health hazards associated with exposure to petrol vapour which include hepatotoxicity (5-7) and oxidative stress $(8,9)$.

Although the hazardous effects of petrol have been previously reported many decades ago (10), recent reports regarding the hazardous effects of petrol exposure and environmental safety resulted in reformulation of petrol constituents which led to the removal of many potentially toxic components from petrol. For instance, there was a switch from the use of leaded petrol to use of unleaded one and there was also introduction of oxygenates to the new petrol formulation $(11,12)$. This approach ensures that little or no harmful heavy metals are present in the petrol mixture and only a limited amount of benzene is traceable in the final reformulated fuel (13). It was recently recommended by the Euro II standard that the research octane number (RON), which is a determinant of fuel performance, should be 97 (14). It also recommended that not more than $500 \mathrm{ppm}$ and $5 \%$ of sulphur and benzene respectively should be present in a given RON 97 petrol formulation. The Malaysian Government therefore consequently proposed to join other countries to move to Euro II standard. Despite such important move, recent literature still suggests that exposure to petrol may be associated with some health problems.

It is suggested that administration with appropriate combination of antioxidant vitamins could possibly ameliorate the toxic effects of exposure to petrol among filling station workers. Petrol-induced oxidative stress was found to be significantly improved among petrochemical station workers following administration of tablets rich in vitamins, micro-elements and flavonoids (15). A number of experiments using animal models have demonstrated that treatments of rats exposed to petrol vapour with vitamins $\mathrm{A}, \mathrm{E}$ and $\mathrm{C}$ was associated with significantly reduced toxicities resulting from the exposure $(6,7,16-18)$. Since it is established that exposure to petrol is associated with oxidative stress (19-22), it can be hypothesized that administration with natural products rich in antioxidants) like honey may improve the adverse effects associated with the exposure.

The last decade has witnessed a renewed research interest on honey. Honey is a natural yellowish-brown fluid formed from nectar by honeybees. Honey contains many antioxidants including catalase, flavonoids, thiamine, riboflavin, pyridoxine, pantothenic acid, ascorbic acid and nicotinic acid (23-27). Several lines of evidence exist to support the antioxidant effects of honey (28). It has been suggested that the antioxidant effect of honey may be due to the synergistic activity of some of its constituents (29). It was also recently observed that administration of honey was associated with amelioration of liver damage in streptozocin-induced diabetic rats (30); it was also shown to be associated with amelioration of oxidative stress in kidneys of diabetic rats (31). Honey was also recently demonstrated to exert protective effect against petrol-induced hepatotoxicity and nephrotoxicity in rats (32). The aim of the present study was therefore to assess the effect of honey administration on oxidants/antioxidants markers and liver function of petrol rats exposed to petrol vapours.

\section{Materials and Methods}

\section{Animals}

This study was approved by the Animal Ethics Committee of Universiti Sains Malaysia [USM/Animal Ethics Approval/2011/ (70) (321)]. A total of 32 male Sprague-Dawley rats aged 6-7 weeks (weighing 170-230 g) were obtained from Animal Research and Service Centre of Universiti Sains Malaysia, Health Campus, Kelantan, Malaysia. The animals were randomly divided in to 4 groups $(n=8)$ and treated as follows:

- Control group (CG): Normal control group, administered $0.5 \mathrm{ml}$ distilled water daily for 11 weeks without exposure to petrol.

- Petrol exposed group (PG): Exposed to petrol vapours $\left(11.13 \pm 1.1 \mathrm{~cm}^{3} / \mathrm{h}, 6\right.$ hours daily, six days per week) and given distilled water $0.5 \mathrm{ml}$ daily for 11 wks

- Honey treated group (HG): Normal control group, treated with honey only $(1.2 \mathrm{~g} / \mathrm{kg}$ body weight $)$ for 11 weeks 
- Petrol + honey group (PH): Exposed to petrol vapours $\left(11.13 \pm 1.1 \mathrm{~cm}^{3} / \mathrm{h}, 6\right.$ hours daily, six days per week) and concomitantly treated with honey (1.2 $\mathrm{g} / \mathrm{kg}$ body weight) daily for 11 weeks

All the experimental procedures were carried out according to the Institutional Guidelines for the Care and Use of Animals for Scientific Research. The animals were housed in typical rat cages with plastic bottoms and metal grid tops (45 x $25 \times 30 \mathrm{~cm}$ high) and were subsequently allowed to acclimatize to the animal house conditions for a minimum of five days with $12 \mathrm{~h}$ light $/ 12 \mathrm{~h}$ dark cycles prior to the experiment.

\section{Source of honey and its preparation}

The Tualang honey (Agromas ${ }^{\circledR}$, Malaysia) used in this study was supplied by Federal Agricultural Marketing Authority (FAMA), Malaysia. This honey was collected in September 2011, filtered to remove solid particles, and then concentrated to $19-20 \%$ of water by oven drying at $40^{\circ} \mathrm{C}$ and was finally packed in to $230 \mathrm{ml}$ bottle container by the supplier.

\section{Treatment of the rats with honey}

The animals that were given honey ( $\mathrm{HG}$ and $\mathrm{PH}$ ) were treated once daily with $1.2 \mathrm{~g} / \mathrm{kg}$ body weight of honey as previously reported (33) according to the duration specified above.

\section{Rats' exposure to petrol vapours}

The animals in the petro exposed groups (PG and $\mathrm{PH}$ ) were exposed to petrol according to a previous study (34). Briefly, the animals were housed in their cages (two per cage). The cages were then positioned in the exposure chamber $(100 \mathrm{~cm} \times 90 \mathrm{~cm} \times 150 \mathrm{~cm})(2$ cages per chamber). Four calibrated $1000 \mathrm{ml}$ cans containing 500 $\mathrm{ml}$ of petrol were then placed in the exposure chamber and the rats were allowed to inhale the vapours evaporating from the can for 6 hours/day. At the end of the experimental period, the animals were sedated and dissected for collection of blood and liver as described below.

\section{Total body weight and liver weight determination}

The total body weight and liver weight of each rat were determined using a digital analytical balance before and after the experimental period and documented as initial body weight (IBW) and final body weight (FBW). The liver weight is expressed per total body weight.

\section{Sample collection and processing}

Approximately twenty hours after termination of the experiment, the animals were anaesthetized with intraperitoneal pentobarbital $(50 \mathrm{mg} / \mathrm{kg})$ and samples were collected and analyzed as follows. Blood sample was collected by cardiac puncture into plain tubes and left to clot after which it was centrifuged at $3000 \mathrm{x}$ g for 20 minutes; serum was then collected and stored at $-80^{\circ} \mathrm{C}$ until use. The serum was used for the following assay: alkaline phosphatase (ALP), alanine transaminase (ALT) and aspartate aminotransferase (AST). The liver was quickly excised, weighed, washed on ice-cold normal saline and immediately stored at $-80^{\circ} \mathrm{C}$ until use. The frozen liver tissue was thawed, homogenized and made to $10 \%$ homogenate $(\mathrm{w} / \mathrm{v})$ in ice-cold Tris-HCI $(0.1 \mathrm{M}, \mathrm{pH}$ 7.4) using glass homogenizing container at $900 \mathrm{rpm}$. The homogenate was then centrifuged at $1000 \mathrm{Xg}$ for 15 minutes and the supernatant was collected and used for the following analyses: total protein, superoxide dismutase (SOD), catalase (CAT), glutathione peroxidase (GPx), glutathione reductase (GR), glutathione-S-transferase (GST), total glutathione (GSH) and reduced glutathione (GSSG).

\section{Biochemical analyses}

The activities of ALP, ALT and AST were assayed using commercially available kits (BioAssay Systems, Hayward, CA, USA). Laboratory kits from Cayman (USA) were used for the assay of total protein and activities of SOD, GPx, GR, GST and CAT. The total GSH and GSSG concentrations were determined using Laboratory kits from Northwest Life Sciences (USA).

\section{Statistical analyses}

Data were analysed using IBM SPSS version 20. The results are expressed as mean (SD). Groups were compared by one-way ANOVA followed by post hoc test to identify differences between two groups. P value $<$ 0.05 was considered statistically significant.

\section{Results}

The initial body weight was not significantly different among all groups of rats. However, at the end of the experimental period, it was observed that the petrol exposed groups ( $\mathrm{PG}$ and $\mathrm{PH})$ had significantly $(\mathrm{p}<0.05)$ reduced total body weight compared to the normal control group (CG) and honey treated group without exposure to petrol $(\mathrm{HG})$. No significant $(\mathrm{p}>0.05)$ difference was observed between $\mathrm{CG}$ versus $\mathrm{HG}$ and PG 
and $\mathrm{PH}$. The results of effects of honey on liver weight and its enzymes activity are presented in Table 1. It shows that exposure to petrol caused statistically significant $(\mathrm{p}<$ 0.05 ) increase in liver weight (hepatomegaly) and that honey treatment did not result in any statistically significant $(p>0.05)$ decrease in liver weight. The results of effects of honey administration on liver enzymes and oxidative markers are presented in Table 2.

Table 1: Effects of honey on petrol-induced hepatomegaly and liver enzymes activity

\begin{tabular}{llllll}
\hline Group & Treatment & liver weight (per body weight) & ALP(IU/L) & ALT (IU/L) & AST (IU/L) \\
\hline CG & Distilled water & $0.0310(0.0017)^{*}$ & $265(65)$ & $60.1(7.9)$ & $72.7(9.6)$ \\
PG & petrol & $0.0388(0.0033)^{* *}$ & $325(63)$ & $61.9(38.4)$ & $72.0(25.8)$ \\
HG & honey & $0.0222(0.0049)^{-}$ & $314(125)$ & $63.3(16.5)$ & $64.2(12.7)$ \\
PH & Petrol + honey & $0.0372(0.0037)^{-}$ & $346(57)$ & $72.5(9.3)$ & $56.2(10.9)$ \\
\hline
\end{tabular}

CG: normal control group, PG: petrol exposed group, HG: honey treated group, PH: petrol exposed, and honey treated group. Data was analyzed using one -way ANOVA followed by post hoc test. Values are expressed as mean (SD), $\mathrm{n}=8,{ }^{*} \quad p=0.001$ compared to $\mathrm{PG},{ }^{* *} p<0.001$ compared with $\mathrm{HG}, \bar{p}<0.001,{ }^{-} p=0.007$.

Table 2: Effects of honey on liver enzymes and antioxidants levels

\begin{tabular}{|c|c|c|c|c|c|c|}
\hline Group & $\begin{array}{c}\text { CAT } \\
\text { (U/mg } \\
\text { protein) }\end{array}$ & $\begin{array}{c}\text { SOD } \\
\text { (U/mg } \\
\text { protein) }\end{array}$ & $\begin{array}{c}\text { GPx } \\
\text { (U/mg } \\
\text { protein) }\end{array}$ & $\begin{array}{c}\text { GR } \\
\text { (U/mg } \\
\text { protein) }\end{array}$ & $\begin{array}{c}\text { GST } \\
\text { (U/mg } \\
\text { protein) }\end{array}$ & $\begin{array}{c}\text { GSH/GSSG } \\
\text { (U/mg } \\
\text { protein) }\end{array}$ \\
\hline $\mathrm{CG}$ & $7.50(1.91)$ & $0.11(0.04)$ & O.50 (0.38) & $\begin{array}{l}0.50 \\
(0.23)\end{array}$ & $\begin{array}{l}24.46 \\
(5.75)\end{array}$ & $3.43(2.02)$ \\
\hline PG & $7.00(1.85)$ & $0.09(0.01)$ & $\underset{* *}{0.57}(0.31)$ & $\begin{array}{l}0.33 \\
(0.16)^{-}\end{array}$ & $\begin{array}{l}32.44 \\
(3.73)\end{array}$ & $4.71(1.35)$ \\
\hline HG & $5.58(1.00)$ & $0.10(0.02)$ & $0.80(0.27)$ & $\begin{array}{l}0.63 \\
(0.14)\end{array}$ & $\begin{array}{l}28.84 \\
(4.91)\end{array}$ & $3.86(1.58)$ \\
\hline PH & $7.20(0.62)$ & $0.10(0.02)$ & $1.27(0.67)$ & $\begin{array}{l}0.30 \\
(0.20)^{-}\end{array}$ & $\begin{array}{l}32.08 \\
(10.45)\end{array}$ & $5.27(1.70)$ \\
\hline
\end{tabular}

CG: normal control group, PG: petrol exposed group, HG: honey treated group, PH: petrol exposed, and honey treated group. Data was analyzed using one -way ANOVA followed by post hoc test. Values are expressed as mean (SD), $\mathbf{n}=8, * p=0.009$ compared to $\mathrm{PH}, * * p=$ 0.019 compared to PH, $p=0.035$ compared to HG, $\bar{p}=0.016$ compared with HG.

\section{Discussion}

The present study demonstrates that exposure to petrol vapours is associated with poor weight gain, hepatomegaly and an imbalance in the oxidants/antioxidants status. The reduced weight seen in petrol exposed group of rats is in agreement with previous reports $(34,35)$. Our study also demonstrates that honey administration may not ameliorate the poor weight again associated with the petrol exposure, which is also in agreement with a previous study (33). It was previously reported that liver is highly susceptible to petrol vapour toxicity (5). The petrol-induced hepatomegaly observed in our study is corroborated by previous studies $(7,36)$ and may suggest liver tissue injury, increased metabolic workload or chronic inflammation due to toxic effects of constituents of petrol such as the hydrocarbons and other additives which may be metabolized in the liver. In this study, honey administration did not result in any significant improvement in the petrol-induced hepatomegaly.

Studies on changes associated with liver enzymes (AST, ALT and ALP) due to exposure to petrol have been inconsistent $(6,7,37-39)$. In the present study, no significant alteration in liver enzymes activity was observed. Our findings on AST and ALT are in agreement with a previous study of petrol station workers (37) but in disagreement with previous studies in animal models (6, $7)$ and human subjects $(38,39)$. The absence of 
significant effect on AST, ALT and ALP in the present study may be partly attributed to the improved quality of Malaysian petrol $(14,40)$ which perhaps differ from other developing countries.

The effects of exposure to petrol may be tissue specific and exposure to petrol can induce oxidative stress in many ways. For instance, benzene which is a constituent of petrol can cause oxidative stress by undergoing metabolic activation resulting in generation of reactive oxygen species (15). Another important constituent of petrol, methyl tertiary butyl ether (MTBE) is predominantly metabolized in the liver and its toxicity may be ascribed to induction of oxidative changes $(20$, 41, 42). A recent study (34) could not establish significant oxidative changes in the erythrocytes of rats exposed to petrol vapours, however, another study (8) demonstrated that exposure to petrol vapours was associated with oxidative stress in liver cells of male and female rats. In the present study, the activity of GPx was found to be significantly higher in $\mathrm{PH}$ group that were exposed to petrol and treated with honey compared to the control group; it was also found to be insignificantly higher in the HG group that received honey without exposure to petrol compared with the remaining groups. This suggests that honey administration was associated with elevated GPx activity. The present study demonstrated a reduced (statistically insignificant) GR activity among PG rats exposed to petrol compared to the normal control group. The GR activity was also significantly lower in PG rats compared to HG rats that received honey without exposure to petrol suggesting that the exposure affected the GR activity.

The present study and another previously reported similar study on Malaysian petrol (34) suggest that petrol-induced toxicities may be milder compared to studies from other countries $(6,7,9,32,43-45)$ in which more severe toxicities were reported. Available findings suggest that the antioxidant effects of honey may depend on several factors which include the nature of the tissue and disease model investigated as well as the origin of the honey itself; hence, this may clarify why honey administration causes increased activity of certain antioxidant enzymes in certain disease model and/or tissue and in other situations causing reduced activity of the same enzymes in another disease model and/or tissue (31-33, 46, 47). In the present study, honey did not appear to show any significant improvement in petrol-induced toxicities.

\section{Conclusions}

Our study suggests that exposure to Malaysian petrol may be associated with less toxicity as evident by lack of alteration in antioxidant levels and Malaysian Tualang honey administration may not ameliorate liver damage associated with the petrol inhalation. Additional research especially in human subjects is warranted to ascertain the toxic effects that may be associated with the currently used Malaysian petrol.

\section{Acknowledgements}

This work was supported by grant no. 304/PPSP/61313007 from Universiti Sains Malaysia (USM).

\section{Conflicts of interest}

The authors declare no conflicts of interest.

\section{References}

1. Mehlman MA. Dangerous properties of petroleum?refining products: Carcinogenicity of motor fuels (Gasoline). Teratog Carcinog Mutagen. 1990;10(5):399-408.

2. Caprino L, Togna GI. Potential health effects of gasoline and its constituents: A review of current literature (19901997) on toxicological data. Environ Health Perspect. 1998;106(3):115.

3. Ekpenyong CE, Asuquo AE. Recent advances in occupational and environmental health hazards of workers exposed to gasoline compounds. Int J Occup Med Environ Health. 2017;30(1):1-26.

4. Wong $O$, Raabe GK. A critical review of cancer epidemiology in the petroleum industry, with a meta-analysis of a combined database of more than 350,000 workers. Regul Toxicol Pharmacol. 2000;32(1):78-98.

5. Uboh FE, Akpanabiatu MI, Eyong EU, Ebong PE, Eka OO. Evaluation of toxicological implications of inhalation exposure to kerosene fumes and petrol fumes in rats. Acta Biologica Szegediensis. 2005;49(3-4):19-22.

6. Uboh FE, Ebong PE, Akpan HD, Usoh IF. Hepatoprotective effect of vitamins $C$ and $E$ against gasoline vapor-induced liver injury in male rats. Turk J Biol. 2012;36:217-23.

7. Uboh FE, Ekaidem IS, Ebong PE, Umoh IB. The Hepatoprotective Effect of Vitamin A against Gasoline Vapor Toxicity in Rats. Gastroenterology Research. 2009;2(3):1627.

8. Uboh FE, Akpanabiatu MI, Atangwho IJ, Ebong PE, Umoh IB. Effect of Gasoline Vapours on serum lipid profile and oxidative stress in hepatocyes of male and female rats. Acta Toxicologica. 2007;15(1):13-8.

9. Owagboriaye F, Dedeke G, Aladesida A, Bamidele J, Olooto $W$. Assessment of the effect of gasoline fume on stress 
hormones, antioxidant status and lipid peroxidation in albino rat. Journal of King Saud University-Science. 2016.

10. Swick D, Jaques A, Walker JC, Estreicher H. Gasoline toxicology: overview of regulatory and product stewardship programs. Regul Toxicol Pharmacol. 2014;70(2 Suppl):S3S12.

11. Ahmed FE. Toxicology and human health effects following exposure to oxygenated or reformulated gasoline. Toxicol Lett. 2001;123(2):89-113.

12. Schuetzle D, Siegl WO, Jensen TE, Dearth MA, Kaiser EW, Gorse $R$, et al. The relationship between gasoline composition and vehicle hydrocarbon emissions: a review of current studies and future research needs. Environ Health Perspect. 1994;102(Suppl 4):3.

13. Costantini MG. Health effects of oxygenated fuels. Environ Health Perspect. 1993;101(Suppl 6):151.

14. Tan P. Government sets new Euro II standard for fuel 2007 [ A v a i l a b $b$ l e fro $\mathrm{m}$ : http://www.paultan.org/2007/02/15/government-sets-neweuro-ii-standard-for-fuel/.

15. Georgieva T, Michailova A, Panev T, Popov T. Possibilities to control the health risk of petrochemical workers. Int Arch Occup Environ Health. 2002; 75:21-6.

16. Uboh F, Akpanabiatu M, Atangwho I, Ebong P, Umoh I. Effect of vitamin A on weight loss and haematotoxicity associated with gasoline vapors exposure in Wistar rats. Int J Pharmacol. 2008;4(1):40-5.

17. Uboh F, Eteng $M$, Ebong P, Umoh I. Vitamins A and E reverse gasoline vapors-induced hematotoxicity and weight loss in female rats. Toxicol Ind Health. 2010;26(9):559-66.

18. Uboh F, Udosen E, Ebong P. Protective effect of vitamin $C$ against gasoline vapours-induced reproductive toxicity in male wistar rats. Acta Endocrinologica (Buc). 2010;6(3):30514.

19. Kinawy A. Impact of gasoline inhalation on some neurobehavioural characteristics of male rats. BMC Physiol. 2009;9(1):21

20. Li D, Liu Q, Gong Y, Huang Y, Han X. Cytotoxicity and oxidative stress study in cultured rat Sertoli cells with Methyl $<$ $i>$ tert $</ i>$-butyl ether (MTBE) exposure. Reprod Toxicol. 2009;27(2):170-6.

21. Raza H, Qureshi M, Montague W. Alteration of glutathione, glutathione S-transferase and lipid peroxidation in mouse skin and extracutaneous tissues after topical application of gasoline. The international journal of biochemistry \& cell biology. 1995;27(3):271-7.

22. Rekhadevi PV, Rahman MF, Mahboob M, Grover $P$. Genotoxicity in filling station attendants exposed to petroleum hydrocarbons. Ann Occup Hyg. 2010;54(8):944-54.

23. Abubakar MB, Abdullah WZ, Sulaiman SA, Suen AB. A Review of Molecular Mechanisms of the Anti-Leukemic Effects of
Phenolic Compounds in Honey. Int J Mol Sci. 2012;13(11):15054-73.

24. Gheldof N, Wang XH, Engeseth NJ. Identification and quantification of antioxidant components of honeys from various floral sources. J Agric Food Chem. 2002;50(21):58707.

25. Haydak M, Palmer L, Tanquary M, Vivino A. Vitamin content of honeys. JNutrition. 1942;23(June):581-8.

26. Kishore RK, Halim AS, Syazana M, Sirajudeen K. Tualang honey has higher phenolic content and greater radical scavenging activity compared with other honey sources. Nutr Res. 2011;31(4):322-5.

27. Schepartz A. Honey catalase: occurrence and some kinetic properties. JApic Res. 1966;5(3):167-76.

28. Erejuwa OO, Sulaiman SA, Ab Wahab MS. Honey: a novel antioxidant. Molecules. 2012;17(4):4400-23.

29. Gil MI, Ferreres F, Ortiz A, Subra E, Tomas-Barberan FA. Plant phenolic metabolites and floral origin of rosemary honey. JAgric Food Chem. 1995;43(11):2833-8.

30. Erejuwa O, Sulaiman $S$, Wahab M, Sirajudeen $K$, Salleh $M$, Gurtu S. Hepatoprotective effect of tualang honey supplementation in streptozotocin-induced diabetic rats. International Journal of Applied Research in Natural Products. 2012;4(4):37-41.

31. Omotayo E, Gurtu S, Sulaiman $S, A b$ Wahab M, Sirajudeen $K$, Salleh M. Hypoglycemic and antioxidant effects of honey supplementation in streptozotocin-induced diabetic rats. International journal for vitamin and nutrition research Internationale Zeitschrift für Vitamin-und Ernährungsforschung Journal international de vitaminologie et de nutrition. 2010;80(1):74.

32. Achuba FI, Nwokogba CC. Effects of honey supplementation on hydrocarbon-induced kidney and liver damage in wistar albino rats. Biokemistri. 2015;27(1):50-5.

33. Abubakar M, Abdullah W, Sulaiman S, Uboh F, Ang B. Effect of honey supplementation on toxicity of gasoline vapor exposure in rats. International Journal of Applied Research in Natural Products. 2013;6(4):16-22.

34. Abubakar MB, AbdullAh WZ, Sulaiman SA, Ang BS. The effects of exposure to petrol vapours on growth, haematological parameters and oxidative markers in spraguedawley male rats. The Malaysian journal of medical sciences: MJMS. 2015;22(1):23.

35. Uboh F, Akpanabiatu M, Alozie Y, Edet E, Ndem J, Ebong P. Comparative effect of vitamins $A$ and $E$ on gasoline vapoursinduced haematotoxicity and weight-loss in male rats. IJPInternational Journal of Pharmacology. 2009;5(3):215-21.

36. Vysko?il A, Tušl M, Obršál J, Zaydlar K. A subchronic inhalation study with unleaded petrol in rats. J Appl Toxicol. 1988;8(4):239-42.

37. Akinosun O, Arinola O, Salimonu L. Immunoglobulin classes 
The Effects of Honey Administration on Petrol-Induced Oxidative Stress and Hepatotoxicity in Sprague-Dawley Male Rats

and liver function tests in Nigerian petrol attendants. Indian Journal of Occupational and Environmental Medicine. 2006;10(2):58.

38. Nwanjo H, Ojiako O. Investigation of the potential health hazards of petrol station attendants in Owerri Nigeria. Journal of Applied Sciences and Environmental Management. 2007;11(2).

39. Neghab M, Hosseinzadeh K, Hassanzadeh J. Early liver and kidney dysfunction associated with occupational exposure to sub-threshold limit value levels of benzene, toluene, and xylenes in unleaded petrol. Safety and health at work. 2015;6(4):312-6.

40. FirdausMarzuki; H, Isa F. CLEAN FUELS FOR A CLEAN MALAYSIAN ENVIRONMENT. 4th Asian Technology Symposium Siem Reap, Cambodia2006.

41. Valipour M, Maghami P, Habibi-Rezaei M, Sadeghpour M, Khademian MA, Mosavi K, et al. Interaction of insulin with methyl tert-butyl ether promotes molten globule-like state and production of reactive oxygen species. Int J Biol Macromol. 2015;80:610-4

42. Li D, Yuan C, Gong Y, Huang Y, Han X. The effects of methyl< $i>$ tert $</ i>$-butyl ether (MTBE) on the male rat reproductive system. Food Chem Toxicol. 2008;46(7):2402-8.

43. Uboh F, Akpanabiatu M, Ekaidem I, Ebong P, Umoh I. Effect of inhalation exposure to gasoline on sex hormones profile in Wistar albino rats. ACTA ENDOCRINOLOGICABUCHAREST-. 2007;3(1):23.

44. Uboh F, Akpanabiatu M, Alozie Y. Comparative effect of gasoline vapours on renal functions in male and female albino wistar rats. J Pharmacol Toxicol. 2008;3(6):478-84.

45. Uboh F, Akpanabiatu M, Ndem J, Alozie Y, Ebong P. Comparative nephrotoxic effect associated with exposure to diesel and gasoline vapours in rats. Journal of Toxicology and Environmental Health Sciences. 2009; 1(4):068-74.

46. Erejuwa O, Sulaiman $S$, Wahab M, Sirajudeen K, Salleh M, Gurtu S. Antioxidant protection of Malaysian tualang honey in pancreas of normal and streptozotocin-induced diabetic rats. Ann Endocrinol. 2010;71(4):291-6.

47. Erejuwa OO, Sulaiman SA, Wahab MSA, Sirajudeen KNS, Salleh MSM, Gurtu S. Differential responses to blood pressure and oxidative stress in streptozotocin-induced diabetic wistarkyoto rats and spontaneously hypertensive rats: effects of antioxidant (Honey) treatment. Int $J$ Mol Sci. 2011;12(3):1888-907. 